\title{
Hubungan antara Kecerdasan Spiritual dengan Resiliensi Akademik Siswa SMK di Semarang Utara
}

\author{
Etika Meiranti ${ }^{1}$, Anwar Sutoyo ${ }^{2}$ \\ 1,2 Jurusan Bimbingan dan Konseling, Universitas Negeri Semarang (UNNES) \\ e-mail: etikamei2898@gmail.com
}

\begin{abstract}
ABSTRAK. Resiliensi akademik penting untuk dimiliki oleh siswa dalam menjalani proses akademiknya. Berdasarkan penelitian awal yang dilakukan oleh peneliti, ditemukan adanya resiliensi akademik yang rendah, sedangkan kecerdasan spiritual yang cenderung tinggi. Penelitian ini bertujuan untuk mengetahui hubungan antara kecerdasan spiritual dengan resiliensi akademik siswa SMK di Semarang Utara. Jenis penelitian yang digunakan dalam penelitian ini yaitu kuantitatif korelasional. Pengambilan sampel menggunakan teknik simple random sampling. Instrumen yang digunakan untuk pengambilan data adalah skala psikologi resiliensi akademik dan kecerdasan spiritual. Analisis data yang digunakan pada uji hipotesis adalah uji korelasional Product Moment Pearson. Penelitian ini memperoleh hasil bahwa terdapat hubungan positif yang signifikan, dengan derajat korelasi yang kuat antara kecerdasan spiritual dengan resiliensi akademik siswa SMK di Semarang Utara. Saran yang dapat peneliti berikan bagi guru BK yaitu untuk memberikan layanan dengan tujuan meningkatkan resiliensi akademik dan kecerdasan spiritual, serta menerapkan kebijakan yang mendukung perkembangan kecerdasan spiritual dan resiliensi akademik.
\end{abstract}

Kata kunci: resiliensi, resiliensi akademik, kecerdasan spiritual

\section{Pendahuluan}

Kemampuan untuk bangkit dan menghadapi suatu persoalan menjadi hal yang perlu dimiliki oleh individu pada saat ini. Kemampuan tersebut dinilai penting, mengingat permasalahan hidup yang semakin kompleks seiring berkembangnya zaman. Kemampuan untuk menghadapi suatu persoalan bisa disebut sebagai resiliensi. Resiliensi merupakan kemampuan individu untuk tetap kuat dan mampu menghadapi serta mengatasi permasalahan atau kesulitan yang menimpanya (Grotberg dalam Ayu, dkk. 2017:15). Permasalahan atau kesulitan yang menimpa seseorang merupakan hal yang unik dan mungkin berbeda pada setiap individu. Penyebab dan latar dari persoalan yang dimiliki individu tersebut juga berbeda-beda. Oleh karena itu, resiliensi diperlukan individu dalam berbagai bidang kehidupan, misalnya dalam keluarga, lingkungan kerja, dan lingkungan akademik. Resiliensi yang dimiliki siswa dalam konteks akademik dapat disebut sebagai resiliensi akademik.

Menurut Hendriani (2018:80), resiliensi akademik yaitu kemampuan seseorang untuk tetap kuat dan tangguh sehingga mampu bangkit ketika mengalami emosional negatif serta situasi sulit dan menekan pada saat menjalankan proses belajar. Kemampuan ini membantu siswa dapat bertahan selama menjalani proses belajarnya, sehingga hasil belajar siswa menjadi optimal. Siswa sangat penting untuk memiliki resiliensi yang baik, tak terkecuali siswa SMK. Siswa SMK berada 
pada masa remaja, di mana pada masa ini individu dipersiapkan untuk memasuki dunia kerja dan mendapat pelatihan kerja tertentu. Desmita (2017:198) menjelaskan bahwa saat ini siswa sangat membutuhkan resiliensi agar dapat menghadapi keadaan-keadaan penuh tantangan dan tekanan yang terjadi pada abad 21 ini. Bahkan dikatakan juga bahwa resiliensi merupakan kemampuan yang dinilai sebagai fondasi atau kekuatan dasar dalam membentuk karakter positif individu. Tanpa adanya resiliensi, siswa tidak akan memililiki keberanian, ketekunan, rasionalitas, dan insight. Resiliensi merupakan kemampuan yang sangat menentukan gaya berpikir dan keberhasilan siswa dalam hidupnya, termasuk keberhasilan dalam belajar di sekolah (Desmita, 2017:199).

Berdasarkan Standar Kompetensi Kemandirian Peserta Didik (SKKPD), siswa SMK memiliki tugas perkembangan dalam aspek pengembangan diri. Tugas perkembangan tersebut yaitu mempersiapkan diri, menerima dan bersikap positif serta dinamis terhadap perubahan fisik dan psikis yang terjadi pada diri sendiri untuk kehidupan yang sehat (Kemdikbud, 2016). Jika melihat tugas perkembangan tersebut, siswa memiliki tugas untuk dapat menyesuaikan diri dengan perubahan dan tuntutan yang dihadapinya. Dengan kata lain, siswa diharapkan mampu memiliki resiliensi akademik yang baik sehingga mampu menghadapi tuntutan akademik. Tuntutan akademik siswa SMK memang tidak dapat dianggap remeh, karena mereka dididik untuk menjadi tenaga kerja yang memiliki keterampilan, mampu memenuhi kebutuhan dunia usaha/industri dan mampu menyesuaikan diri dengan perkembangan ilmu pengetahuan, teknologi, dan seni (Kemdikbud, 2018:2).

Oleh karena itu, jika melihat tugas perkembangan dan tuntutannya, maka sangat penting bagi siswa SMK untuk memiliki resiliensi yang baik. Menurut Hendriani (2018:84), resiliensi akademik memiliki empat dimensi, yaitu confidence (self-belief), control (a sense of control), composure (anxiety), dan commitment (persistence). Confidence (self-belief) merupakan keyakinan yang dimiliki siswa sehingga mereka percaya bahwa mereka mampu menghadapi tugas sekolah dengan usahanya meskipun menjumpai tantangan atau kesulitan. Control (a sense of control) merupakan kemampuan siswa untuk melakukan tugas dengan baik yang ditunjukkan dengan kemampuan siswa dalam mengelola dan mengendalikan tuntutan atau tantangan yang dia hadapi dalam proses belajarnya. Composure (anxiety) merupakan kemampuan siswa untuk mengelola perasaan cemas dan khawatir akan pekerjaan atau tugas yang dimiliki. Perasaan tersebut muncul karena takut mereka tidak dapat melakukan pekerjaan atau tugas sekolah dengan baik. Sedangkan commitment (persistence) merupakan kemampuan siswa untuk terus berusaha menyelesaikan atau melewati tantangan dalam mengerjakan tugas sekolahnya. Jika siswa memiliki nilai yang baik pada keempat dimensi tersebut bisa dikatakan dia memiliki resiliensi akademik yang baik, begitupun sebaliknya.

Berdasarkan wawancara terhadap siswa SMK Pelayaran Wira Samudera di Semarang Utara, yang dilakukan oleh peneliti pada 10 Januari 2020, menunjukkan beberapa ciri resiliensi akademik yang rendah. Jika dilihat dari dimensi resiliensi akademik, responden memiliki confidence yang kurang, ditandai dengan ketakutan karena merasa belum mampu melakukan tugasnya. Mereka juga memiliki control yang kurang baik, dilihat dari kemampuan mereka yang kurang dalam mengelola tuntutannya, sampai mereka merasakan kelelahan, pusing, sakit kepala, mudah kelelahan, kurang tidur, dan tidak nafsu makan. Ketakutan dan kecemasan yang dialami oleh siswa menunjukkan kurangnya kemampuan siswa dalam mengelola perasaan cemasnya, yang berarti mereka kurang dalam dimensi composure. Bahkan, mereka juga memiliki commitment 
yang kurang, dibuktikan dengan keinginannya untuk menghindari tuntutan akademiknya. Hal ini menunjukkan bahwa resiliensi akademik merupakan keterampilan yang tidak mudah untuk dimiliki oleh seseorang.

Resiliensi akademik penting untuk dimiliki oleh siswa dalam menjalani proses akademiknya. Dikhawatirkan jika siswa tidak memiliki resiliensi akademik yang baik, siswa akan mengalami stress akademik. Stress akademik merupakan suatu kondisi di mana siswa tidak mampu menghadapi tuntutan akademik dan menganggap bahwa tuntutan akademik adalah sebuah gangguan baginya (Barseli, dkk., 2017:143). Kekhawatiran ini berdasarkan pada hasil penelitian yang dilakukan oleh Septiani dan Fitria (2016:71) yang menyatakan bahwa resiliensi berhubungan negatif dengan stress, yang berarti semakin tinggi resiliensi yang dimiliki individu maka akan semakin rendah stress yang dimiliki oleh individu tersebut. Begitu pula sebaliknya, jika resiliensi yang dimiliki individu rendah, maka stress akan semakin tinggi. Oleh karena itu, sangat penting bagi seorang siswa untuk memiliki resiliensi akademik.

Terdapat beberapa faktor yang berhubungan dengan resiliensi akademik. Berdasarkan hasil penelitian yang dilakukan oleh Aryadelina dan Laksmiwati (2019:8), menyatakan bahwa siswa yang merasa sangat terpuruk dengan keadaannya memiliki keyakinan bahwa semua kejadian dapat terjadi karena kehendak Tuhan, dan dia yakin bahwa dia dapat mengambil pelajaran dari kesulitannya. Oleh karena itu, siswa tersebut mampu untuk bertahan dan bangkit dari keterpurukannya, yang berarti dia memiliki resiliensi yang baik. Hasil penelitian ini dapat menjelaskan bahwa siswa dapat memiliki resiliensi yang disebabkan oleh dua hal. Pertama, keyakinan bahwa suatu kejadian berhubungan dengan keberadaan Tuhan, dan yang kedua yaitu kemampuan dalam mengambil pelajaran atau hikmah dari sebuah kejadian. Keyakinan seseorang akan adanya keterkaitan suatu kejadian dengan keberadaan Tuhan disebut spiritualitas (Rosyadi, Kusbaryanto, dan Yuniarti, 2019:110). Temuan ini sesuai dengan pernyataan Matthew Tull dalam Munawaroh dan Mashudi (2019:85), yang menyatakan bahwa spiritualitas sebagai salah satu ciri individu yang resilien. Sedangkan, kemampuan dalam mengambil pelajaran atau hikmah dari sebuah kejadian disebut kecerdasan spiritual.

Zohar dan Marshall (2007:3), menjelaskan bahwa kecerdasan spiritual merupakan kemampuan yang dimiliki seseorang untuk menghadapi dan memecahkan permasalahan dengan menilai makna dari suatu peristiwa dalam kehidupan, dan menganggap bahwa tindakan atau jalan hidup individu lebih bermakna daripada yang lain. Terdapat penelitian terdahulu yang meneliti hubungan kecerdasan spiritual dengan resiliensi. Finka dan Prasetya (2018:106) dalam penelitiannya, menunjukkan bahwa terdapat hubungan yang positif antara kecerdasan spiritual dengan resiliensi. Hal ini menunjukkan bahwa semakin tinggi kecerdasan spiritual, maka semakin tinggi pula resiliensi, begitupun sebaliknya. Studi pendahuluan dilakukan oleh peneliti di SMK Pelayaran Wira Samudera yang terletak di Kecamatan Semarang Utara. Peneliti memberikan skala psikologi resiliensi akademik dan kecerdasan spiritual kepada 72 responden, dan diperoleh hasil bahwa terdapat $0,00 \%$ siswa memiliki resiliensi sangat rendah, $22,22 \%$ siswa memiliki resiliensi akademik yang rendah, 54,17\% siswa memiliki resiliensi akademik sedang, 23,61\% siswa memiliki resiliensi akademik tinggi, dan 0,00\% siswa memiliki resiliensi sangat tinggi. Hal ini menunjukkan kondisi resiliensi akademik pada siswa bervariasi dari rendah, sedang, hingga tinggi. Meskipun hanya $22,22 \%$ siswa yang memiliki resiliensi akademik rendah, tetapi jumlah ini tidak dapat disepelekan. Karena, resiliensi akademik sangat penting bagi kegiatan belajar siswa. Bahkan dikatakan oleh Desmita $(2017,199)$ bahwa resiliensi akademik memiliki peran yang sangat besar 
dalam menentukan keberhasilan siswa dalam proses belajarnya. Sedangkan, hasil skala kecerdasan spiritual menunjukkan bahwa 65,28\% siswa memiliki kecerdasan spiritual tinggi dan 34,72\% siswa memiliki kecerdasan spiritual sangat tinggi. Studi ini menunjukkan kecerdasan spiritual yang cenderung tinggi dan resiliensi akademik yang bervariasi dari rendah, sedang, hingga tinggi. Hal ini menunjukkan kesenjangan antara studi pendahuluan dengan penelitian terdahulu yang menunjukkan semakin tinggi kecerdasan spiritual maka semakin tinggi pula resiliensi. Seharusnya, jika siswa sudah memiliki kecerdasan spiritual yang tinggi, mereka juga memiliki resiliensi akademik yang tinggi. Fenomena ini menarik perhatian peneliti untuk meneliti lebih dalam keterkaitan antara kecerdasan spiritual dengan resiliensi akademik.

Melihat rendahnya resiliensi akademik yang ada di sekolah, peran bimbingan dan konseling sangat diperlukan untuk membantu siswa mencapai salah satu tugas perkembangan berdasarkan SKKPD yang terkait aspek pengembangan diri. Guru bimbingan dan konseling atau biasa disebut guru BK dapat membantu siswa untuk memiliki resiliensi akademik yang baik dengan memberikan berbagai layanan. Pernyataan tersebut sesuai dengan peraturan Menteri Pendidikan dan Kebudayaan Republik Indonesia no. 111 tahun 2014 tentang bimbingan dan konseling pada pendidikan dasar dan pendidikan menengah pasal 3 yang berbunyi "Layanan bimbingan dan konseling memiliki tujuan membantu konseli mencapai perkembangan optimal dan kemandirian secara utuh dalam aspek pribadi, belajar, sosial, dan karir". Guru BK dapat membantu pencapaian perkembangan dalam bidang pribadi dengan memberikan layanan terkait kecerdasan spiritual untuk peningkatan resiliensi akademik. Guru BK perlu memberikan layanan dengan optimal, mengingat pentingnya pengembangan diri siswa, khususnya terkait kecerdasan spiritual. Diharapkan setelah memperoleh layanan tentang kecerdasan spiritual, siswa akan memiliki resiliensi akademik yang baik sehingga siswa mampu menghadapi kesulitan yang ada dalam kegiatan belajarnya. Sehingga, diharapkan siswa akan memperoleh hasil belajar yang optimal. Oleh karena itu, peneliti tertarik untuk melakukan penelitian tentang Hubungan antara Kecerdasan Spiritual dengan Resiliensi Akademik Siswa SMK di Semarang Utara.

\section{Metode}

Jenis penelitian yang akan dilakukan oleh peneliti merupakan penelitian korelasional. Penelitian korelasional dalam praktiknya perlu melalui langkah-langkah yang dijelaskan oleh oleh Yusuf (2017:65) sebagai berikut: (1) merumuskan permasalahan; (2) mencari literasi untuk mengetahui dasar teori dan penelitianpenelitian terdahulu; (3) melakukan identifikasi terhadap variabel penelitian; (4) menentukan sampel, instrumen atau alat untuk memperoleh data, dan teknik analisis data yang sesuai dengan penelitian; (5) melakukan pengumpulan data; (6) mengolah dan menginterpretasi data; (7) menyusun laporan penelitian.

Populasi dalam penelitian ini yaitu seluruh siswa SMK di Semarang Utara, yang terdiri atas tiga SMK dengan rincian jumlah siswa sebagai berikut

Tabel 1. Populasi Penelitian

\begin{tabular}{ccc}
\hline No & Nama SMK & Jumlah Siswa \\
\hline 1 & SMK Negeri 10 Semarang & 1.096 \\
2 & SMK Negeri Jateng di Semarang & 355 \\
3 & SMK Pelayaran Wira Samudera & 110 \\
& Jumlah & $\mathbf{1 . 5 6 1}$ \\
\hline
\end{tabular}


Teknik pengambilan sampel yang digunakan oleh peneliti yaitu menggunakan teknik simple random sampling. Peneliti menggunakan taraf kesalahan 5\% dengan menggunakan pengambilan sampel berdasarkan Isaac dan Michael dalam Sugiyono (2017:128). Dengan jumlah populasi 1.561 maka sampel yang diambil berjumlah 283 dengan rincian sebagai berikut::

Tabel 2. Sampel Penelitian

\begin{tabular}{cccc}
\hline Nama SMK & Jumlah Siswa & Rumus Sampel & Jumlah sampel \\
\hline SMK Negeri 10 Semarang & 1.096 & $\frac{1.096}{1.561} \times 283$ & 199 \\
SMK Negeri Jateng di Semarang & 355 & $\frac{355}{1.561} \times 283$ & 64 \\
SMK Pelayaran Wira Samudera & 110 & $\frac{110}{1.561} \times 283$ & 20 \\
Jumlah total & $\mathbf{1 . 5 6 1}$ & & $\mathbf{2 8 3}$ \\
\hline
\end{tabular}

Peneliti menggunakan skala psikologi sebagai alat pengumpul data untuk mengungkap kedua variabel. Resiliensi akademik diungkap menggunakan skala resiliensi akademik, sedangkan kecerdasan spiritual diungkap menggunakan skala kecerdasan spiritual. Teknik analisis data yang digunakan oleh peneliti adalah korelasi product moment Pearson.

\section{Temuan}

Dari data yang diperoleh, ditemukan gambaran kecerdasan spiritual sebagaimana sajian pada table 3. berikut:

Tabel 3. Gambaran Kecerdasan Spiritual

\begin{tabular}{cccccc}
\hline Variabel & $\begin{array}{c}\text { Jumlah } \\
\text { Responden (N) }\end{array}$ & $\begin{array}{c}\text { Nilai } \\
\text { Maximum }\end{array}$ & $\begin{array}{c}\text { Nilai } \\
\text { Minimum }\end{array}$ & $\begin{array}{c}\text { Rata-Rata } \\
\text { (Mean) }\end{array}$ & $\begin{array}{c}\text { Standar } \\
\text { Deviasi }\end{array}$ \\
\hline $\begin{array}{c}\text { Kecerdasan } \\
\text { Spiritual }\end{array}$ & 283 & 215 & 110 & 172,28 & 18,72 \\
\hline
\end{tabular}

Tabel di atas menunjukkan perolehan data kecerdasan spiritual siswa SMK di Semarang Utara yang diperoleh dari 283 responden, memiliki nilai maksimum 215, nilai minimum sebesar 110, rata-rata nilai sebesar 172,28, serta standar deviasi sebesar 18,72. Dari data tersebut, dapat diklasifikasikan menjadi lima kategori untuk mengetahui gambaran kecerdasan spiritual siswa SMK di Semarang Utara, sebagai berikut

Tabel 4. Klasifikasi Kecerdasan Spiritual

\begin{tabular}{cccc}
\hline Kategori & Interval & Jumlah & Prosentase \\
\hline Sangat Tinggi & $>206$ & 7 & $2 \%$ \\
Tinggi & $185-206$ & 63 & $22 \%$ \\
Sedang & $162-184$ & 136 & $48 \%$ \\
Rendah & $139-161$ & 66 & $23 \%$ \\
Sangat Rendah & $<139$ & 11 & $4 \%$ \\
\hline
\end{tabular}

Berdasarkan tabel tersebut, dapat dilihat prosentase tingkat kecedasan spiritual siswa SMK di Semarang Utara. Siswa SMK di Semarang Utara yang memiliki kecerdasan spiritual sangat tinggi dengan perolehan skor $>206$ sejumlah 7 siswa dengan prosentase $2 \%$. Siswa yang memiliki kecerdasan spiritual tinggi dengan skor antara 185 sampai 206 sejumlah 63 siswa dengan 
prosentase $22 \%$. Siswa yang memiliki kecerdasan spiritual sedang dengan skor antara 162 sampai 184 sejumlah 136 dengan prosentase 48\%. Siswa yang memiliki kecerdasan spiritual rendah dengan skor antara 139 sampai 161 berjumlah 66 dengan prosentase 23\%. Sedangkan, siswa yang memiliki kecerdasan spiritual sangat rendah dengan skor kurang dari 139 terdiri atas 11 siswa dengan prosentase 4\%. Perolehan ini menunjukkan bahwa mayoritas siswa SMK di Semarang Utara memiliki kecerdasan spiritual sedang, yaitu sebesar 48\%. Selanjutnya, diperoleh gambaran resiliensi akademik sebagai berikut:

Tabel 5. Gambaran Resiliensi Akademik

\begin{tabular}{cccccc}
\hline Variabel & $\begin{array}{c}\text { Jumlah } \\
\text { Responden (N) }\end{array}$ & $\begin{array}{c}\text { Nilai } \\
\text { Maximum }\end{array}$ & $\begin{array}{c}\text { Nilai } \\
\text { Minimum }\end{array}$ & $\begin{array}{c}\text { Rata-Rata } \\
\text { (Mean) }\end{array}$ & $\begin{array}{c}\text { Standar } \\
\text { Deviasi }\end{array}$ \\
\hline Resiliensi Akademik & 283 & 194 & 93 & 138,24 & 17,64 \\
\hline
\end{tabular}

Tabel di atas menunjukkan perolehan data resiliensi akademik siswa SMK di Semarang Utara yang diperoleh dari 283 responden, memiliki nilai maksimum 194, nilai minimum sebesar 93, rata-rata nilai sebesar 138,24, serta standar deviasi sebesar 17,64. Dari data tersebut, dapat diklasifikasikan menjadi lima kategori untuk mengetahui gambaran resiliensi akademik siswa SMK di Semarang Utara sebagai berikut:

Tabel 6. Klasifikasi Resiliensi Akademik Siswa

\begin{tabular}{cccc}
\hline Kategori & Interval & Jumlah & Prosentase \\
\hline Sangat Tinggi & $>170$ & 14 & $5 \%$ \\
Tinggi & $150-170$ & 59 & $21 \%$ \\
Sedang & $129-149$ & 126 & $45 \%$ \\
Rendah & $106-128$ & 79 & $28 \%$ \\
Sangat Rendah & $<106$ & 5 & $2 \%$ \\
\hline
\end{tabular}

Berdasarkan tabel tersebut, dapat dilihat prosentase tingkat resiliensi akademik siswa SMK di Semarang Utara. Siswa SMK di Semarang Utara yang memiliki resiliensi akademik sangat tinggi dengan perolehan skor $>170$ sejumlah 14 siswa dengan prosentase 5\%. Siswa yang memiliki resiliensi akademik tinggi dengan skor antara 150 sampai 170 sejumlah 59 siswa dengan prosentase $21 \%$. Siswa yang memiliki resiliensi akademik sedang dengan skor antara 129 sampai 149 sejumlah 126 dengan prosentase 45\%. Siswa yang memiliki resiliensi akademik rendah dengan skor antara 106 sampai 128 berjumlah 79 dengan prosentase 28\%. Sedangkan, siswa yang memiliki resiliensi akademik sangat rendah dengan skor kurang dari 106 terdiri atas 5 siswa dengan prosentase $2 \%$. Perolehan ini menunjukkan bahwa mayoritas siswa SMK di Semarang Utara memiliki resiliensi akademik sedang, yaitu sebesar $45 \%$.

Hubungan antara kecerdasan spiritual dengan resiliensi akademik siswa SMK di Semarang Utara dapat diketahui dengan melakukan uji korelasi product moment. Pengujian korelasi product moment dilakukan dengan menggunakan aplikasi IBM SPSS Statistics 21. Sebelum dilakukan uji korelasi, terlebih dahulu dilakukan uji asumsi klasik, yaitu uji normalitas dan uji linieritas data.

Pengujian normalitas data dilakukan dengan menggunakan Kolmogorov-Smirnov melalui aplikasi IBM SPSS Statistics 21. Untuk menentukan normal atau tidaknya data tersebut, pengambilan keputusan didasakan pada indeks Kolmogorov-Smirnov, dengan hasil sebagai berikut: 
Tabel 7. Hasil Uji Normalitas

\begin{tabular}{ccc}
\hline Jumlah Responden & Nilai Signifikansi (Sig.) & Keterangan \\
\hline 283 & 0,522 & Normal \\
\hline
\end{tabular}

Tabel tersebut menunjukkan nilai signifikansi dari uji normalitas Kolmogorov-Smirnov sebesar 0,522 >0,05 yang berarti data dari lapangan berdistribusi normal. Selanjutnya dilakukan uji linieritas dengan hasil sebagai berikut:

Tabel 8. Hasil Uji Linieritas

\begin{tabular}{ccc}
\hline Variabel & Signifikansi (Sig.) Deviation of Linearity & Keterangan \\
\hline $\begin{array}{l}\text { Kecerdasan Spiritual } \\
\text { Resiliensi Akademik }\end{array}$ & 0,464 & Linier \\
\hline
\end{tabular}

Tabel tersebut menunjukkan bahwa nilai signifikansi deviation of linearity adalah 0,464 $>0,05$. Dengan demikian, dapat disimpulkan bahwa terdapat hubungan yang linier antara variabel kecerdasan spiritual dengan resiliensi akademik. Maka, penelitian ini memenuhi syarat untuk dilakukan pengolahan data menggunakan uji korelasi product moment menggunakan indeks Pearson. berikut:

Setelah dilakukan uji korelasi menggunakan Product Moment Pearson, didapatkan hasil sebagai

Tabe1 9. Hasil Uji Korelasi

\begin{tabular}{ccccc}
\hline Variabel & Jumlah Responden $\mathbf{( N )}$ & $\mathbf{r}_{\mathbf{x}}$ & $\mathbf{r}_{\mathbf{y}}$ & Sig. (2-tailed) (P) \\
\hline Kecerdasan Spiritual & 283 & 1 & 0,637 & 0,000 \\
Resiliensi Akademik & 283 & 0,637 & 1 & 0,000 \\
\hline
\end{tabular}

Berdasarkan table tersebut, dapat dilihat bahwa nilai signifikansi kedua variabel tersebut adalah $0,000(\mathrm{p}=0,000<0,05)$ yang berarti terdapat hubungan antara kecerdasan spiritual dengan resiliensi akademik. Karena nilai pearson correlation atau (rx dan ry) bernilai positif, maka variabel kecerdasan spiritual dan resiliensi akademik memiliki hubungan yang positif. Kemudian, diperoleh nilai korelasi sebesar 0,637 yang berarti kedua variabel memiliki derajat hubungan yang kuat, karena berada pada rentang 0,600-0,799 derajat interpretasi koefisien korelasi.

\section{Diskusi}

Resiliensi akademik merupakan salah satu kemampuan yang penting untuk dimiliki oleh siswa, terutama siswa SMK. Banyaknya beban akademik dan tuntutan untuk mampu mempersiapkan diri memasuki dunia kerja membuat siswa SMK sangat membutuhkan resiliensi akademik yang baik. Penelitian ini bertujuan untuk mengetahui hubungan antara kecerdasan spiritual dengan resiliensi akademik.

Hasil penelitian menunjukkan adanya keragaman tingkat kecerdasan spiritual siswa SMK di Semarang Utara. Kecerdasan spiritual siswa SMK di Semarang Utara berkisar dari kategori sangat rendah hingga sangat tinggi, dan mayoritas berada pada kategori sedang. Hal ini berarti bahwa sebagian besar siswa SMK di Semarang Utara memiliki kecerdasan spiritual yang baik, tetapi masih perlu peningkatan pada beberapa siswa. Keberagaman tingkat kecerdasan spiritual ini merupakan sesuatu yang wajar terjadi, karena perbedaan individu dan latar belakang individu. Menurut Yusuf dalam Rosad (2020, 131), terdapat beberapa faktor yang mempengaruhi tinggi rendahnya kecerdasan spiritual individu, yaitu faktor internal berupa pembawaan atau fitrah, dan faktor eksternal yang berasal dari lingkungan keluarga, sekolah, dan masyarakat. 
Pembawaan atau fitrah individu sebagai manusia yaitu memiliki naluri agama yang baik. Hal ini menjadi salah satu faktor yang mempengaruhi kecerdasan spiritual. Jadi, pada dasarnya semua siswa dilahirkan memiliki fitrah yang baik. Fitrah yang baik ini menjadikan siswa memiliki kecerdasan spiritual yang baik pula. Namun, fitrah tersebut dapat berubah karena faktor eksternal atau faktor lingkungan, sehingga pada akhirnya muncul perbedaan tingkat kecerdasan spiritual pada siswa.

Lingkungan keluarga merupakan salah satu faktor yang mempengaruhi kecerdasan spiritual. keluarga sebagai madrasah pertama bagi individu, tentu saja sangat berperan dalam perkembangan kecerdasan spiritual siswa. Keluarga yang mendukung perkembangan kecerdasan spiritual anak, seperti mengajarkan anak untuk mengenal Tuhannya, mengajak anak untuk melaksanakan perintah Tuhan dan menjauhi larangan-Nya, dan mengajarkan untuk percaya diri dalam berbuat kebaikan, serta bersabar. Keluarga yang demikian memiliki kecenderungan membentuk individu memiliki kecerdasan spiritual yang tinggi. Sedangkan, adanya siswa yang memiliki kecerdasan spiritual di bawah rata-rata mungkin berasal dari latar belakang lingkungan yang kurang mendukung perkembangan kecerdasan spiritualnya.

Tidak cukup hanya lingkungan keluarga, lingkungan sekolah dan lingkungan masyarakat juga mempengaruhi kecerdasan spiritual. Lingkungan sekolah yang mendukung berkembangnya kecerdasan spiritual siswanya, seperti sekolah yang mengajarkan untuk menjunjung tinggi nilai ketuhanan, membiasakan iri untuk berani berbuat kebaikan dan malu untuk melanggar perintah Tuhan, serta mengajarkan kesabaran. Sekolah yang demikian akan menciptakan siswa yang memiliki kecerdasan spiritual cenderung tinggi. Tentu saja jika lingkungan masyarakat tempat siswa tinggal juga mendukungnya. Adanya kecerdasan spiritual yang rendah bisa jadi karena siswa berada pada lingkungan yang kurang mendukung perkembangan kecerdasan spiritual siswa tersebut, entah lingkungan keluarganya, sekolah, ataupun lingkungan masyarakat tempat dia tinggal.

Hasil penelitian menunjukkan bahwa resiliensi akademik siswa SMK di Semarang Utara bervariasi dari kategori sangat rendah hingga sangat tinggi. Akan tetapi, mayoritas siswa berada pada kategori sedang. Hal tersebut menggambarkan bahwa sebagian besar siswa SMK di Semarang Utara mampu menghadapi dan bangkit dari tekanan akademik dengan baik, tetapi masih perlu peningkatan lagi pada beberapa siswa. Keberagaman tingkat resiliensi akademik ini tidak terlepas dari keberagaman individu dan latar belakangnya.

Rojas dalam Hendriani (2019:85), menyebutkan bahwa resiliensi akademik dipengaruhi oleh dukungan sosial berupa bimbingan dan dukungan keluarga. Bimbingan dan dukungan keluarga yang diterima oleh individu akan membuat individu tersebut lebih yakin dan lebih kuat dalam menghadapi kesulitan ataupun masalah. Siswa SMK di Semarang Utara yang memiliki keluarga penuh bimbingan dan dukungan, terutama dalam bidang akademik, memungkinkan siswa memiliki resiliensi akademik yang cenderung tinggi. Namun, tidak semua siswa memiliki keluarga yang penuh bimbingan dan dukungan, sehingga memunculkan adanya variasi tingkat resiliensi akademik.

Selain bimbingan dan dukungan keluarga, ada faktor lain yang mempengaruhi resiliensi akademik. Hendriani (2019:86) juga menyebutkan bahwa faktor personal atau karakteristik individu menjadi faktor yang mempengaruhi resiliensi akademik. Faktor tersebut diantaranya optimisme, ketekunan, dan motivasi. Siswa yang memiliki optimisme, ketekunan, serta motivasi yang tinggi akan membuat dia memiliki resiliensi akademik yang cenderung tinggi pula. Karena, 
sifat optimisme, ketekunan, dan motivasi yang ada pada diri siswa akan membantu dia untuk terus berusaha dan terdorong untuk terus bangkit jika dia mengalami kesulitan.

Berdasarkan hasil penelitian yang telah dilakukan, diperoleh kesimpulan bahwa terdapat hubungan positif yang signifikan, dengan derajat korelasi yang kuat antara kecerdasan spiritual dengan resiliensi akademik siswa SMK di Semarang Utara. Artinya, bila kecerdasan spiritual siswa tinggi, maka akan tinggi pula resiliensi akademiknya, dan sebaliknya bila rendah kecerdasan spiritual siswa, maka rendah pula resiliensi akademiknya. Hal ini sejalan dengan pernyataan Dewi, Tarmidzi, dan Choiriyah (2019:17), yang mengatakan bahwa individu yang memiliki kecerdasan spiritual baik akan mampu menyelesaikan dan menghadapi masalah atau tekanan dengan melihatnya dari sisi positif dan maknanya, sehingga dia mampu menyelesaikan masalah tersebut dengan baik.

Kecerdasan spiritual dianggap sebagai kecerdasan yang paling tinggi. Sakti dan Alim (2019:121) menyebutkan bahwa kecerdasan spiritual adalah fondasi yang diperlukan untuk mengaktifkan kecerdasan intelijen dan kecerdasan emosi secara efektif. Dengan memiliki kecerdasan spiritual yang baik, maka memungkinkan individu untuk mampu menghadapi dan menyelesaikan permasalahan dengan baik atau memiliki resiliensi yang baik, karena keefektifan kecerdasan intelijen dan kecerdasan emosi dalam dirinya. Oleh karena itu, sangat penting bagi seseorang untuk memiliki kecerdasan spiritual yang baik.

Salah satu komponen dari kecerdasan spiritual menurut Sudi, Sham, dan Yama (2017:7), yaitu kesabaran yang tinggi. Kesabaran juga dinilai sebagai komponen tertinggi dalam kecerdasan spiritual. Kesabaran berarti kemampuan individu untuk mengatasi stress atau tekanan, mampu mengatasi tantangan dan hambatan, mampu menghadapi kesulitan, dan pantang menyerah. Pada komponen ini, sejalan dengan konsep resiliensi akademik, di mana Munawaroh dan Mashudi (2019:130) menyatakan bahwa resiliensi akademik merupakan kemampuan siswa untuk bangkit dari stress atau tekanan yang bersumber dari akademik atau bidang belajar. Oleh karena itu, siswa yang memiliki kecerdasan spiritual yang tinggi, jika menghadapi kesulitan dalam proses belajarnya, dia akan menggunakan kemampuannya untuk tidak menyerah dan terus berusaha untuk bangkit dari kesulitannya tersebut, yang berarti dia memiliki resiliensi akademik yang tinggi.

Kelemahan dari penelitan ini yaitu dilakukan dalam masa pandemi covid-19 sehingga tidak dapat bertemu langsung dengan responden untuk pengambilan datanya. Sehingga, peneliti harus menulis dengan jelas instruksi pengisian instrumennya agar responden dapat memahami maksud dari instruksinya. Mengingat pentingnya kecerdasan spiritual dan resiliensi akademik dalam proses pembelajaran, guru BK hendaknya memberikan layanan baik dalam format kelompok atau klasikal untuk meningkatkan kedua variabel tersebut. Selain itu, dapat juga dilakukan penerapan kebijakan yang mendukung perkembangan kecerdasan spiritual dan resiliensi akademik. Bagi peneliti selanjutnya yang tertarik untuk meneliti variabel resiliensi akademik, dapat melakukan penelitian dengan mencari faktor lain yang dapat mempengaruhi resiliensi akademik. Selain itu, dapat juga melakukan penelitian mengenai cara untuk meningkatkan resiliensi akademik.

\section{Simpulan}

Simpulan penelitian ini menunjukkan Kecerdasan spiritual siswa SMK di Semarang Utara berada pada kategori yang bervariasi dari sangat rendah hingga sangat tinggi, tetapi mayoritas berada pada kategori sedang. Keberagaman tingkat kecerdasan spiritual ini dapat terjadi karena 
beberapa faktor, diantaranya faktor internal berupa pembawaan atau fitrah, dan faktor eksternal yang berasal dari lingkungan keluarga, sekolah, dan masyarakat. Kemudian resiliensi akademik siswa SMK di Semarang Utara berada pada kategori yang bervariasi dari sangat rendah hingga sangat tinggi, tetapi mayoritas berada pada kategori sedang. Perbedaan tingkat resiliensi akademik ini dapat terjadi karena beberapa faktor, diantaranya bimbingan dan dukungan keluarga, serta karakteristik individu yang meliputi optimisme, ketekunan, dan motivasi. Seterusnya Terdapat hubungan positif yang signifikan, dengan derajat korelasi yang kuat antara kecerdasan spiritual dengan resiliensi akademik siswa SMK di Semarang Utara. Artinya, semakin tinggi kecerdasan spiritual siswa, maka semakin tinggi pula resiliensi akademiknya, dan sebaliknya semakin rendah kecerdasan spiritual siswa, maka semakin rendah pula resiliensi akademiknya

\section{Referensi}

Abidin, A. M. (2019). Pengaruh Penerapan Kegiatan Keagamaan di Lembaga Pendidikan Formal Terhadap Peningkatan Kecerdasan Spiritual Anak. An Nisa' Jurnal Studi Gender dan Anak, $12(1), 570-582$.

Annas, A. N. (2017). Manajemen Peserta Didik Berbasis Kecerdasan Spiritual Pendidikan Islam. TADBIR : Jurnal Manajemen Pendidikan Islam, 5 (2), 132-142.

Aryadelina dan Laksmiwati. (2019). Resiliensi Remaja dengan Latar Belakang Orang Tua yang Bercerai. Character: Jurnal Penelitian Psikologi, 6 (2), 1-10.

Ayu, dkk. (2017). Gambaran Resiliensi pada Remaja. Jurnal Keperawatan 'Aisyiyah (JKA), 4 (1), 13 21.

Baezzat, Motaghedifard, dan Bakht. (2019). Predicting Students' Subjective Well-Being and Its Subscales Based on Spiritual Intelligence. International Journal of Psychology, 13 (2), 89-108.

Barmi, dkk. (2019). The Relationship between Spiritual Intelligence and Resiliency of Rehabilitation Staf. Journal of Pastoral Care \& Counseling, 73 (4), 205-210.

Barseli, Ifdil, dan Nikmarijal. (2017). Konsep Stress Akademik Siswa. Jurnal Konseling dan Pendidikan, 5 (3), 143-148.

Cahyani dan Rahmasari. (2019). Resiliensi pada Remaja Awal yang Orangtuanya Bercerai. Indonesian Psychological Research, 1 (2), 36-44.

Cassidy, S. (2016). The Academic Resilience Scale (ARS-30): A New Multidimensional Construct Measure. Frontiers in Psychology, 7 (1787), 1-11.

Desmita. (2017). Psikologi Perkembangan Peserta Didik. Bandung: PT Remaja Rosdakarya.

Dewi, Romayanti, dan Gorda. (2019). Pengaruh Kecerdasan Emosional dan Kecerdasan Spiritual terhadap Kepuasan Kerja dan Kinerja Perawat. SINTESA Prosiding (pp. 473-480). Universitas Dhyana Putra.

Dewi, Tarmizi, dan Choiriyah. (2019). Pengaruh Kecerdasan Spiritual, Konsep Diri, dan Dukungan Sosial terhadap Kecemasan Menghadapi Masa Pensiun Pegawai Universitas Islam Negeri Raden Fatah Palembang. Yönetim, 2 (1), 15-32.

Fadhlurrohman dan Indriana. (2019). Kecerdasan Spiritual pada Pengguna dan Pengedar Narkoba di Lapas Kedungpane Semarang. Jurnal Empati, 8 (1), 93-98.

Faiz, A., Yandri, H., Kadafi, A., Mulyani, R. R., Nofrita, N., \& Juliawati, D. (2019). Pendekatan Tazkiyatun An-Nafs untuk membantu mengurangi emosi negatif klien. Counsellia: Jurnal Bimbingan dan Konseling, 9(1), 65-78. 
Finka dan Prasetya. (2018). Relationship Between Spiritual Intelligence with Resilience in Teenagers Born in Poor Families. Journal Psikodimensia, 17 (2), 103-109.

Fradelos, E. C. (2019). Connecting the Dots: Understanding the Relationship Between Religiosity, Psychological Resilience and Depression in Breast Cancer Patients. Progress in Health Sciences, 9 (1), 98-104.

Gaol, Khumaedi, dan Masrukan. (2017). Pengembangan Instrumen Penilaian Karakter Percaya Diri pada Mata Pelajaran Matematika Sekolah Menengah Pertama. Journal of Educational Research and Evaluation, 6 (1), 63-70.

Gustiana, Sulistiani, dan Rosliana. (2016). Hubungan Kecerdasan Emosi dengan Resiliensi pada Penghuni Lapas di Kelas II A Samarinda. Jurnal Motivasi, 3 (1), 1-18.

Hadi, S. (2016). Statistik. Yogyakarta: Pustaka Pelajar.

Hendriani, W. (2018). Resiliensi Psikologis Sebuah Pengantar. Jakarta Timur: Prenadamedia Group.

Idris dan Ulum. (2019). Pelestarian Aspek Spiritual Santri di Madrasah Diniyah Nurul Ulum Pandansari Senduro Lumajang. Tarbiyatuna: Jurnal Pendidikan Islam, 12 (1), 96-117.

Kemdikbud. (2016). KBBI Daring. tersedia di https://kbbi.kemdikbud.go.id/, diakses pada 08/02/2020.

Kemendikbud. (2014). Peraturan Menteri Pendidikan dan Kebudayaan Republik. Indonesia Nomor 111 Tabbun 2014 Tentang Bimbingan dan Konseling pada Pendidikan Dasar dan Pendidikan Menengah. Jakarta.

Kemendikbud. (2016). Panduan Operasional Penyelenggaraan Bimbingan dan Konseling Sekolah Menengah Kejuruan (SMK). Jakarta.

Kemendikbud. (2018). Peraturan Menteri Pendidikan dan Kebudayaan Nomor 34 Tabun 2018 Tentang Standar Nasional Pendidikan Sekolah Menengah Kejuruan/Madrasah Aliyah Kejuruan. Jakarta.

Maesaroh, M. (2019). Intensitas Dzikir Ratib Al-Haddad dan Kecerdasan Spiritual Santri. Irsyad: Jurnal Bimbingan, Penyuluban, Konseling, dan Psikoterapi Islam, 7 (1), 61-84.

Mudaim, Karwono, dan Agustina. (2019). Hubungan Antara Konsep Diri dengan Resiliensi Peserta Didik Kelas X SMA Negeri 1 Batanghari Lampung Timur Tahun Pelajaran 2019/2020. Counseling Milenial, 1 (1), 31-39.

Munawaroh dan Mashudi. (2019). Resiliensi: Kemampuan Bertahan dalam Tekanan dan Bangkit dari Keterpurukan. Semarang: CV Pilar Nusantara.

Nejad, dkk. (2019). Effectivenessof Spiritual Intelligence in Resilience and Responsibility of Students. Int J School Health, 6 (3), 1-7.

Nurseha dan Pertiwi. (2019). Determinan Pernikahan Dini di Desa Semendaran Kota Cilegon. Jurnal Kesehatan dan Kedokteran, 15 (1), 22-35.

Poerwanto dan Prihastiwi. (2017). Analisis Prediktor Resiliensi Akademik Siswa Sekolah Menengah Pertama di Kota Surabaya. Psikosains, 12 (1), 45-57.

Rosad, W. S. (2020). Pelaksanaan Shalat Dhuha dalam Meningkatkan Kecerdasan Spiritual Siswa Kelas 3 Madrasah Ibtidaiyah Ma'arif NU Ajibarang Wetan. Al-Muqkidz: Jurnal Kajian Keislaman, 8 (1), 119-138.

Rosyadi, Kuebaryanto, dan Yuniarti. (2019). Literatur Review Aspek Spiritualitas / Religiusitas dan Perawatan Berbasis Spiritual / Religius pada Pasien Kanker. Jurnal Kesehatan Karya Husada, 7 (1), 108-127.

Saifuddin, Ahmad. (2020). Penyusunan Skala Psikologi. Jakarta: Kencana. 
Sakti dan Alim. (2019). The Portrait of Spiritual Intelligence and Aggressiveness of University Students . Jurnal Psikologi Pendidikan \& Konseling, 5 (2), 120-126.

Sari dan Indrawati. (2016). Hubungan Antara Dukungan Sosial Teman Sebdaya dengan Resiliensi Akademik pada Mahasiswa Tingkat Akhir Jurusan X Fakultas Teknik Universitas Diponegoro. Jurnal Empati, 5 (2), 177-182.

Septiani dan Fitria. (2016). Hubungan Antara Resiliensi dengan Stress pada Mahasiswa Sekolah Tinggi Kedinasan. Jurnal Penelitian Psikologi, 7 (2), 59-76.

Sholih, dkk. (2017). Meningkatkan Resiliensi Remaja melalui Bibliocounseling. Jurnal Penelitian Bimbingan dan Konseling, 2 (1), 51-61.

Solehudin, M. (2018). Peran Guru PAI dalam Mengembangkan Kecerdasan Emosional (EQ) dan Kecerdasan Spiritual (SQ) Siswa SMK Komputama Majenang. Jurnal Tawadhu, 1 (3), 303325.

Sudi, Sham, dan Yama. (2017). Kecerdasan Spiritual Menurut Perspektif Hadis. Al-Irsyad, 2 (2), 1 11.

Sugiyono. (2017). Metode Penelitian Pendidikan: Pendekatan Kuantitatif, Kualitatif, dan R\&D. Bandung: Alfabeta.

Syahril. (2019). Commitment of Principal in Implementing Tasks in High School First State in Padang. INA-Rxiv, 1-7.

Ulandari, Y., \& Juliawati, D. (2019). Pemanfaatan layanan bimbingan kelompok untuk meningkatkan kecerdasan emosi siswa. Indonesian Journal of Counseling and Development, 1(1), 18.

Ursia, Siaputra, dan Sutanto. (2013). Prokrastinasi Akademik dan Self-Control pada Mahasiswa Skripsi Fakultas Psikologi Universitas Surabaya. Makara Seri Sosial Humaniora, 17 (1), 1-18.

Wahidah. (2018). Resiliensi Akademik Perspektif Psikologi Islam. Proceeding National Conference Psikologi UMG, (pp. 111-140). Yogyakarta.

Yuwono, B. (2010). SQ Reformation: Rahasia Pribadi Cerdas Spiritual "Genius Hakiki". Jakarta: Gramedia Pustaka Utama.

Zohar dan Marshall. (2007). SQ: Spiritual Intelligence The Ultimate Intelligence. Bandung: Penerbit Mizan Media Utama 